\title{
OYE este es un NO LUGAR
}

\author{
Maria Lorena Cueva Ramirez
}

Universidad de Jáen

RESUMEN

Con esta contribución quiero visibilizar espacios que excluyen a las personas con discapacidad auditiva. Espacios cotidianos y completamente integrados en el paisaje de las personas oyentes y, que pueden pasar desapercibidos pero que, por su situación, organización y características resultan lugares totalmente inaccesibles para las personas sordas.

Además de poner en común estos espacios y hacerlos visibles, busco con esta propuesta una acción activista que nos ayude a ponernos en la piel de las personas sordas, haciendo visibles NO LUGARES que podamos ir encontrando en nuestro contexto más cercano.

PALAVRAS CLAVE: Arte Educação; Educação Artística; Necessidades Educativas Especiais. E

\section{RESUMO}

Com essa contribuição, quero criar espaços visíveis que excluam pessoas com deficiências auditivas. Espaços diários completamente integrados na paisagem dos ouvintes e que podem passar despercebidos, mas que, devido à sua situação, organização e características, são locais totalmente inacessíveis para pessoas surdas.

Além de colocar esses espaços em comum e torná-los visíveis, busco com essa proposta uma ação ativista que nos ajude a nos colocar no lugar dos surdos, tornando visíveis NÃO LUGAR que possamos encontrar em nosso contexto mais próximo.

PALAVRAS-CHAVE: Art Education; Artistic Education; Special Educational Needs. 


\section{VISIBILIZANDO CREENCIAS}

A diario, las personas sordas encuentran, en su paisaje cotidiano, espacios en los que se sienten excluidos, NO LUGARES. Estos espacios pueden pasar completamente desapercibidos para las personas oyentes que desconocen las características del colectivo sordo.

Es cierto que en nuestra sociedad hay una serie de creencias instauradas que, de alguna forma, hacen que las personas oyentes que no tenemos en nuestro entorno alguna personas con discapacidad auditiva, pensemos que en nuestra sociedad esta comunidad está completamente incluida.

Pensamos, por lo tanto, que ya no tienen ninguna barrera que les impida desenvolverse de forma autónoma en cualquier contexto social. Creemos que a través de la lectura labial pueden comunicarse con otras personas sin ninguna dificultad o, que en su defecto, si escribimos lo que queremos contarles, pueden entender el texto íntegramente. También encontramos esos casos típicos, de personas que omiten el dato fundamental de que este grupo de personas tienen un problema auditivo y que, aunque le hablemos muy alto y hagamos miles de aspavientos, es muy probable que en ningún caso entiendan qué estamos diciendo. Además, tal y como explica el doctor tinerfeño José Juan

Barajas, premiado por la American Academy of Audiology es muy importante tener en cuenta que:

El fin último de un programa de atención a las personas con discapacidad auditiva debe ser la integración social, que puede verse dificultada por la no aceptación del defecto auditivo en primera instancia. Se debe tener en cuenta que la pérdida de audición puede implicar aislamiento y cambios emocionales lo suficientemente serios como para perder interés por la principal obligación que tiene un ser vivo: la de vivir. Además, puede tener gran repercusión en el entorno familiar, laboral y social. Los niños y jóvenes pueden experimentar dificultades de aprendizaje, lo cual afecta negativamente al proceso de integración escolar. En todo caso, hay que sensibilizar, a la vez que instruir, a la población para que entienda el mundo del sordo. Es importante dotar los espacios públicos y privados de las condiciones de accesibilidad necesarias para las personas con discapacidad auditiva. (como se cita en Delgado, R., 2017)

Llama la atención como características tan importantes y básicas de personas sordas y de su cotidianeidad, pasan completamente desapercibidas para todos aquellos que no tenemos a alguien que sufra esta realidad cerca. Características desconocidas que hacen que desconozcamos al mismo tiempo a un colectivo que forma parte de nuestra sociedad. Un desconocimiento social que los hacen invisibles. $Y$ es que posiblemente, ese sea uno de los factores que potencian el desconocimiento hacia este colectivo. No se trata de una discapacidad visible, no podemos identificar a una persona sorda a simple vista por la calle. Esa invisibilidad de la discapacidad, ese pasar desapercibido, ese no llamar la atención visual de la sociedad, me hace pensar en la frase popular de "si no lo veo, no existe".

Si al no tratarse de una discapacidad perceptible a simple vista por las personas, le sumamos la poca repercusión y apoyo institucional que recibe este colectivo, podríamos decir que en este caso, a quien podríamos tachar de sorda e incluso, de ciega, es a la sociedad que no es consciente de una realidad que viven miles de sus componentes.

Estas falsas creencias provienen de un lugar realmente peligroso, el desconocimiento. Muchas de ellas son mitos sociales que se han asumido porque pueden resultar más cómodos para la mayoría de las personas. Ya que, en muchos casos, entendemos que al ser ellos los "diferentes" deben ser los que busquen las alternativas y se esfuercen por entendernos y viceversa. Y, a pesar de esta situación, damos por hecho y nos sentimos muy orgullosos de decir que nuestra sociedad es una sociedad inclusiva.

\section{CONOCER}

Sin embargo, al contrario de lo que podamos creer, no todas las personas con discapacidad auditiva pueden leer los labios. Una realidad fundamental en el grueso del colectivo sordo es que, sin el apoyo de la Lengua de Signos, pierden mucha información durante la comunicación, además de mantener de forma continúa el contacto visual mientras se está hablando, para que así, ellos puedan entender el carácter de nuestra conversación.

A eso, le sumamos el hecho de que, en la mayoría de los casos, las personas sordas profundas (no perciben ningún tipo de sonido, ni cuentan con implante o audífono) solo se comunican mediante la LSE (Lengua de Signos Española), y la estructura gramatical de esta lengua es completamente distinta a la estructura gramatical de la lengua española.

Por ejemplo si las personas oyentes decimos "Mi tío no tenía un coche rojo" esta misma frase con la estructura gramatical de la LSE sería "Antes padre mío hermano suyo coche rojo no hay". Evidentemente, si a una persona con estas características le escribimos un texto para comunicarnos con ella es muy complicado que entienda nuestro mensaje.

\section{IDENTIFIQUEMOS LOS NO LUGARES:}

Ahora que conocemos algunas de las barreras principales a las que se enfrentan las personas sordas la propuesta consiste en generar un movimiento artivista que tenga como objetivo identificar esos NO LOGARES. Ser conscientes de estos lugares y llegar a hacerlos visibles lo conseguiremos a través de la empatía y poniéndonos en la piel de las personas que componen esta comunidad. 
La herramienta que nos permitirá hacerlos visibles es la fotografía. Para recopilar estas fotografías en un espacio público y común se creará un banco de imágenes en las redes sociales. Esta imágenes estarán acompañadas de su localización geográfica y de una descripción del autor en la que se explique cuáles son las características de ese NO LUGAR.

La razón por la que compartir este tipo de imágenes de denuncia en las redes sociales es por las facilidades que nos da este soporte. Podemos compartir las imágenes para darle más difusión, comentar posibles soluciones y crear un circuito de relación no solo a nivel nacional y que tal y como indica Bourriaud:

La posibilidad de un arte relacional -un arte que tomaría como horizonte teórico la esfera de las interacciones humanas y su contexto social, más que la afirmación de un espacio simbólico autónomo y privado- da cuenta de un cambio radical de los objetivos estéticos, culturales y políticos puestos en juego por el arte moderno.

(Bourriaud, N., 2006)

Está claro que el poder de difusión que ofrecen las redes sociales a día de hoy es bastante destacable. Te permiten llegar a cualquier esfera social con un solo "click" y compartir de forma masiva imágenes, textos y vídeos. Al hilo de lo que comenta Bourriaud:

La obras producen espacios-tiempo relacionales, experiencias interhumanas que tratan de liberarse de las obligaciones de la ideología de la comunicación de masas, de los espacios en los que se elaboran; generan, en cierta medida, esquemas sociales alternativos, modelos críticos de las construcciones de la relaciones amistosas. (Borriaud, N., 2006)

\section{REFERENCIAS}

Bourriaud, N. (2006). Estética relacional. Adriana Hidalgo Editora, Buenos Aires.

Delgado, Román (2017) “La sordera puede implicar aislamiento y cambios emocionales tan serios como para perder interés por la vida", eldiario.es.

Consultado en: http://www.eldiario.es/tenerifeahora/

sociedad/implicaraislamiento-

cambios-emocionales-interes_0_628887510.html 